\title{
HUBUNGAN EFIKASI DIRI DENGAN KEMAMPUAN ORIENTASI MOBILITAS SISWA TUNANETRA SLB A YKAB SURAKARTA
}

\author{
Ersa Mayori ${ }^{1}$, Munawir Yusuf ${ }^{2}$, Subagya $^{3}$ \\ ${ }^{123}$ Universitas Sebelas Maret, Indonesia \\ Email: ersa_mayori@student.uns.ac.id
}

\section{INFORMASI ARTIKEL}

Terkirim 16-Juli-2021

Revisi 03-Agustus-2021

Diterima 05-Agustus-2021

Kata kunci:

efikasi diri, kemampuan

orientasi mobilitas, siswa

tunanetra.

\begin{abstract}
ABSTRAK
Penelitian ini bertujuan untuk mengetahui hubungan antara efikasi diri dengan kemampuan orientasi mobilitas siswa tunanetra di SLB A YKAB Surakarta. Penelitian ini adalah penelitian kuantitatif dengan desain korelasional. Subjek dalam penelitian ini adalah seluruh siswa tunanetra SLB A YKAB Surakarta. Penentuan subjek pada penelitian ini dilakukan dengan teknik purposif sampling. Teknik pengumpulan data dalam penelitian ini dengan menggunakan angket efikasi diri dan tes kinerja kemampuan orientasi mobilitas. Penelitian ini menggunakan teknik uji validitas isi oleh para ahli (expert judgement) sebagai validator yang selanjutnya dihitung menggunakan Aiken's $V$. Pada uji reliabilitasnya menggunakan Interclass Correlation Coefficient dengan bantuan SPSS 26. Teknik analisis data yang digunakan pada penelitian ini adalah analisis korelasi Sperman Rank. Hasil uji korelasi dalam penelitian ini menunjukkan nilai koefisien korelasi sebesar 0,654 dengan nilai $r_{\text {tabel }}$ 0,591, sehingga $r_{\text {hitung }}>r_{\text {tabel }}$ untuk taraf signifikansi 0,05 . Berdasarkan hasil penelitian dan analisis data yang telah dilakukan, dapat disimpulkan bahwa terdapat hubungan positif yang signifikan antara efikasi diri dengan kemampuan orientasi mobilias siswa tunanetra SLB A YKAB Surakarta.
\end{abstract}

\section{Pendahuluan}

Anak yang mengalami hambatan dalam segi mental maupun fisik merupakan anak dengan berkebutuhan khusus. Ada beberapa macam anak dengan berkebutuhan khusus di antaranya tunalaras, tunarungu, tunagrahita, autisme, tunanetra, dan lain sebagainya. Salah satu jenis atau macam anak dengan berkebutuhan khusus adalah tunanetra. Tunanetra merupakan keadaan dimana individu mengalami gangguan ataupun hambatan yang terjadi pada indra penglihatan (Kustawan \& Meimulyani, 2013). Menurut Widaningrum (2013) mengemukakan tunanetra adalah individu yang mempunyai intensitas penglihatan sentral pada 20/200 kaki atau individu tersebut hanya dapat menggunakan penglihatan dengan kejauhan 20 kaki atau 6 meter ataupun kurang dari 6 meter. Tunanetra merupakan individu yang memiliki hambatan pengelihatan baik low vision (kurang penglihatan) ataupun blind (buta total) imbas dari kerusakan yang terjadi pada indera penglihatannya (Pandji \& Wardhani, 2013:4). Dapat ditarik sebuah kesimpulan dari beberapa pedapat tersebut bahwa tunanetra merupakan individu yang mengalami gangguan ataupun hambatan pada indera pengelihatan sehingga membutuhkan pelayanan khusus.

Akibat dari ketunanetraan yang dialami membuat seorang tunanetra minim dalam mendapatkan informasi karena banyaknya informasi yang didapat manusia bersumber dari penglihatannya. Lowenfeld (Sunanto, 2005) mengatakan bahwa akibat ketunanetraan yang dialami mengakibatkan keterbatasan dalam kemampuan bergerak, minimnya dalam hal luas dan variasi pengalaman, serta 
mengontrol dan berinteraksi dengan lingkungan sekitar. Menurut Wahyuno (2013) menyebutkan ciri individu dengan hambatan pengelihatan salah satunya yaitu ketergantungan yang berlebih akibat dari tidak dikuasainya keterampilan orientasi dan mobilitas yang berdapmapk pada minimnya kemampuan dalam bergerak dan berpindah tempat yang mengakibatkan individu dengan hambatan pengelihatan selalu membutuhkan bantuan orang lain dalam segala aktivitasnya.

Berbagai macam hambatan yang timbul akibat dari gangguan penglihatan meliputi kesulitan ketika melihat benda yang ada di hadapan individu, hambatan dalam interaksi sosial, kesulitan orientasi mobilitas, hingga hambatan pada kegiatan sehari-hari. Menurut Turnbull dkk (2013) individu dengan tunanetra mengalami tiga hambatan yaitu hambatan pada lingkup keberagaman pengalaman, hambatan dalam berinteraksi dengan lingkungan, dan hambatan dalam berpindah tempat atau orientasi mobilitas. Hambatan berpindah tempat atau orientasi mobilitas merupakan hambatan pokok yang dialami oleh seorang tunanetra. Hidayat dan Suwandi (2013) mengatakan orientasi dan mobilitas adalah perhimpunan dan penggunaan indera-indera yang masih dapat berfungsi dengan aman, tepat, dan efektif serta efisien tanpa bergantung pada orang lain. Selain itu, orientasi dan mobilitas memiliki keunggulan antara lain dapat mengenal lingkungan, perpindahan dari satu tempat ke tempat yang lainnya, mengidentifikasi tempat disekitarnya, membantu diri sendiri maupun orang di sekelilingnya.

Keterampilan mobilitas yaitu keterampilan untuk bergerak secara bebas dilingkungan merupakan keterampilan yang paling terpengaruh untuk penyesuaian sosial pada tunanetra. Hallahan dan Kauffman (Sunanto, 2005) mengemukakan bahwa tunanetra bervariasi dalam keterampilan orientasi mobilitasnya, sukar untuk menentukan sumber yang membuat seorang tunanetra memiliki kemampuan yang unggul dalam keterampilan orientasi mobilitas, faktor terpenting yang menentukan kemampuan orientasi mobilitas tunanetra yaitu motivasi untuk mau bergerak. Tanpa penguasaan kemampuan orientasi mobilitas, individu tunanetra memiliki sikap pasif, dan kurang percaya diri serta memiliki ketakutan pada berbagai hal, dimana hal tersebut dapat berdampak pada aspek pertumbuhan dan perkembangannya (Widjaya, 2012). Pratama, dkk (2019) mengemukakan bahwa keterampilan yang harus dimiliki oleh individu tunanetra agar dapat hidup secara mandiri adalah penguasaan pada orientasi dan mobilitas yang baik maka akan membantu individu tunanetra menjadi seorang pejalan yang percaya diri serta dapat berjalan mandiri ketika mereka di tempat yang sudah dikuasai maupun yang belum dikuasai.

Hasil pengamatan yang dilakukan selama kegiatan Magang Kependidikan 3 pada SLB A YKAB Surakarta, beberapa siswa tunanetra dalam pelaksanaan Orientasi Mobilitas di sekolah masih membutuhkan bantuan orang awas sedangkan untuk fasilitas penunjang dalam melakukan orientasi dan mobilitas telah tersedia dengan baik. Beberapa diantaranya adanya guiding block, serta adanya tulisan Braille di setiap pintu kelas. Hal tersebut menandakan bahwa siswa tunanetra belum bisa bergerak mandiri dan masih bergantung pada orang lain. Kondisi tersebut dapat disebabkan oleh bebrbagai macam faktor salah satunya yaitu efikasi diri atau keyakinan akan kemampuan mereka dalam berpindah tempat.

Menurut King (2012), efikasi diri merupakan suatu keyakinan individu untuk menguasai suatu situasi dan mampu menghasilkan berbagai hasil positif. Sebagaimana yang telah dikemukakan oleh Myers (Charlos, dkk,2006) seseorang yang memperlihatkan sikap yang tidak cemas, lebih gigih, dan 
tidak mengalami tekanan dalam menghadapi suatu situasi merupakan orang dengan tingkatan selfefficacy tinggi. Alwisol (2009), mengatakan efikasi diri adalah suatu keyakinan seseorang mengenai kemampuan yang dimilikinya. Efikasi diri berkaitan erat dengan keyakinan individu untuk mampu melakukan tindakan sesuai dengan yang diinginkannya. Beberapa individu yang memiliki kompetensi yang sama akan berbeda dalam capaian keberhasilannya, dimana individu yang melakukan suatu tugas dengan penuh keyakinan akan lebih mungkin untuk menyelesaikan tugas tersebut dibandingkan dengan individu yang mengerjakan tugas tidak penuh dengan keyakin maka tidak akan mempu menyelesaikan tugas tersebut (Ormrod, 2008).

Besaran usaha yang dilakukan dan seberapa konsisten individu bertahan dalam menghadapi hambatan atau pengalaman yang membuatnya tidak nyaman merupakan pikiran individu terhadap efikasi diri. Ketika efikasi diri dikaitkan dengan orientasi dan mobilitas tunanetra, sehingga efikasi diri dapat didefinisikan sebagai keyakinan yang dimiliki oleh individu tentang kemampuannya untuk dapat mengarahkan kemampuan kognisinya, motivasinya, dan dalam mengambil tindakan yang diperlukan untuk berpindah tempat. Penelitian sebelumnya mengenai hubungan efikasi diri dan kemandirian dengan judul Hubungan Antara Self Efficacy dan Kecerdasan Emosional dengan Kemandirian Pada Remaja oleh Ema Uzlifatul Jannah (2013) menunjukkan adanya hubungan antara self efficacy dan kemandirian menunjukkan hasil $\mathrm{t}=3,312 \mathrm{p}=0,002(\mathrm{p}<0,001)$, dimana semakin tinggi self efficacy yang dilaksanakan oleh remaja akan semakin tinggi tingkat kemandirian remaja tersebut. Selain itu terdapat penelitian lain dengan judul Efikasi Diri Akademik Mahasiswa Tunanetra oleh Meify Bahar dkk didapatkan hasil bahwa mahasiswa tunanetra memiliki kendala dalam menjalani perkuliahan dan memiliki berbagai sumber efikasi diri akademik yang berbeda baik yang berasal dari diri individu itu sendiri, maupun pengaruh individu lain yang membuat mahasiswa tunanetra tersebut merasa mampu dan yakin untuk menjalani perkuliahan sampai tujuan yang diharapkan dapat tercapai. Berdasarkan uraian diatas diduga bahwa efikasi diri mempengaruhi kemampuan orientasi mobilitas tunanetra, sehingga peneliti ingin mengetahui "Hubungan antara Efikasi Diri dengan Kemampuan Orientasi Mobilitas Siswa Tunanetra SLB A YKAB Surakarta".

\section{Metode}

Penelitian ini menggunakan pendekatan kuantitatif dengan jenis penelitian korelasional dan menggunakan desain penelitian survey dan penilaian kinerja. Penelitian ini bersifat korelasional karena bertujuan untuk mengetahui hubungan antara satu variabel dengan variabel lain, serta menggunakan desain penelitian survey karena menggunakan kuesioner sebagai instrumen penelitian dan penilaian kinerja dalam teknik pengumpulan data. Teknik pengambilan sampel yang digunakan dalam penelitian ini adalah non probability sampel, dengan menggunakan purposive sampling. Teknik pengambilan data non probability sampling merupakan teknik pengambilan sampel yang tidak memberi kesempatan yang sama bagi anggota populasi untuk menjadi sampel. Teknik pengumpulan data pada penelitian ini menggunakan instrumen penelitian berupa angket untuk variabel efikasi diri dan penilaian kinerja untuk variabel kemampuan orientasi mobilitas.

Angket efikasi diri yang digunakan pada penelitian ini menggunakan model skala likert berdasarkan aspek dan indikator efikasi diri selanjutnya dikembangkan menjadi butir-butir pernyataan. 
Instrumen efikasi diri yang digunakan dalam penelitian ini memiliki lima pilihan jawaban, yakni sangat setuju, setuju, netral, tidak setuju, sangat tidak setuju dengan jumlah penyataan atau pertanyaan sebanyak 28 butir. Sedangkan untuk penilaian kinerja kemampuan orientasi mobilitas pada penelitian ini berdasarkan rubrik penilaian dari 1 sampai 3, dimana siswa mendapat nilai 1 ketika belum mampu melakukan dengan benar dan mandiri, mendapatkan nilai 2 ketika siswa mampu melakukan dengan benar meskipun kurang sempurna dan memerlukan bantuan, dan mendapat nilai 3 ketika siswa mampu melakukan dengan benar dan mandiri. Instrumen penilaian kinerja kemampuan orientasi mobilitas sebanyak 47 butir.

Penelitian ini menggunakan teknik uji validitas isi oleh para ahli (expert judgement) sebagai validator yang selanjutnya dihitung menggunakan Aiken's $V$. Pada uji reliabilitasnya menggunakan Interclass Correlation Coefficient dengan bantuan SPSS 26. Selanjutnya data yang telah didapat dianalisis mengunakan korelasi spearman rank, setelah data dianalisis lalu data diinterpretasikan dalam 5 kategori yaitu sangat rendah, rendah, sendang, kuat, sangat kuat (Sugiyono, 2010).

Tabel. Interpretasi Korelasi Spearman Rank

\begin{tabular}{ll}
\hline \multicolumn{1}{c}{$\mathbf{r}^{\mathbf{i}}$} & \multicolumn{1}{c}{ Interpretasi } \\
\hline $0,00-0,199$ & Sangat Rendah \\
\hline $0,20-0,399$ & Rendah \\
\hline $0,40-0,599$ & Sedang \\
\hline $0,60-0,799$ & Kuat \\
\hline $0,80-1,00$ & Sangat Kuat \\
\hline
\end{tabular}

\section{Hasil Penelitian dan Pembahasan}

Penelitian ini menggunakan analisis bivariate correlation atau korelasi sederhana. Uji hipotesis dilakukan menggunakan rumus spearman rank correlation yang dibantu dengan perangkat lunak SPSS 26. Pengujian hipotesis bertujuan untuk mengetahui hubungan antara variabel efikasi diri (X) dengan variabel kemampuan orientasi mobilitas (Y). Hasil dari sebaran data efikiasi diri dan kemampuan orientasi mobilitas siswa tunanetra SLB A YKAB Surakarta disajikan dalam tabel di bawah ini.

Tabel. Sebaran Data Efikasi Diri dan Kemampuan Orientasi Mobilitas

\begin{tabular}{lccccc}
\hline NAMA & KELAS & USIA & Jenis kelamin & $\begin{array}{c}\text { Nilai Efikasi } \\
\text { Diri }\end{array}$ & $\begin{array}{c}\text { Nilai Kemampuan } \\
\text { Orientasi Mobilitas }\end{array}$ \\
\hline JIA & 1A & 8 & Laki-laki & 84 & 109 \\
\hline IAFM & $3 \mathrm{~A}$ & 12 & Laki-laki & 89 & 121 \\
\hline AK & $3 \mathrm{~A}$ & 10 & Laki-laki & 107 & 121 \\
\hline MAK & $3 \mathrm{~A}$ & 9 & Laki-laki & 78 & 114 \\
\hline $\mathrm{N}$ & $3 \mathrm{~A}$ & 9 & Perempuan & 85 & 109 \\
\hline
\end{tabular}




\begin{tabular}{lcclll}
\hline APMA & $3 \mathrm{~A}$ & 8 & Perempuan & 87 & 95 \\
\hline WAA & $6 \mathrm{~A}$ & 13 & Perempuan & 77 & 85 \\
\hline UM & $7 \mathrm{~A}$ & 14 & Perempuan & 85 & 128 \\
\hline DWDA & $8 \mathrm{~A}$ & 14 & Perempuan & 85 & 125 \\
\hline MPP & $8 \mathrm{~A}$ & 14 & Laki-laki & 92 & 126 \\
\hline IM & $9 \mathrm{~A}$ & 19 & Laki-laki & 90 & 131 \\
\hline TPS & $9 \mathrm{~A}$ & 17 & Perempuan & 120 & 132 \\
\hline
\end{tabular}

Berdasarkan tabel di atas sebaran nilai efikasi diri dan kemampuan orientasi mobilitas siswa tunanetra SLB A YKAB Surakarta selanjutnya dikorelasikan untuk menguji hubungan antara variabel efikasi diri (X) dan variabel kemampuan orientasi mobilitas (Y). Hasil uji hipotesis menggunakan korelasi spearman rank ditunjukkan pada tabel berikut ini.

Tabel. Hasil Uji Korelasi Efikasi Diri dan Kemampuan Orientasi Mobilitas

\section{Correlations}

\begin{tabular}{|c|c|c|c|c|}
\hline & & & $\begin{array}{c}\text { Efikasi } \\
\text { Diri }\end{array}$ & $\begin{array}{c}\text { Kemampuan Orientasi } \\
\text { Mobilitas }\end{array}$ \\
\hline \multirow[t]{7}{*}{$\begin{array}{l}\text { Spearman's } \\
\text { rho }\end{array}$} & \multirow[t]{3}{*}{ EfikasiDiri } & $\begin{array}{l}\text { Correlation } \\
\text { Coefficient }\end{array}$ & 1.000 & $.654^{*}$ \\
\hline & & Sig. (2-tailed) & . & .021 \\
\hline & & $\mathrm{N}$ & 12 & 12 \\
\hline & \multirow{4}{*}{$\begin{array}{l}\text { Kemampuan } \\
\text { OrientasiMo } \\
\text { bilitas }\end{array}$} & Correlation & $.654^{*}$ & 1.000 \\
\hline & & Coefficient & & \\
\hline & & Sig. (2-tailed) & .021 & \\
\hline & & $\mathrm{N}$ & 12 & 12 \\
\hline
\end{tabular}

Hasil analisis menggunakan spearman rank correlation yang dibantu dengan program SPSS 26, didapatkan hasil variabel efikasi diri dan kemampuan orientasi mobilitas atau nilai $\mathrm{r}_{\text {hitung }} 0,654$ dengan nilai $r_{\text {tabel }}$ 0,591, sehingga dapat dikatakan $r_{\text {hitung }}>r_{\text {tabel }}$ untuk taraf signifikansi 5\%. Sesuai dengan interpretasi koefisien korelasi spearman rank menurut Sugiyono (2010), nilai tersebut menandakan tingkat korelasi yang kuat antara variabel efikasi diri dan variabel kemampuan orientasi mobilitas. Angka koefisien korelasi bernilai positif 0,654 sehingga dapat diartikan bahwa hubungan variabel efikasi diri dan kemampuan orientasi mobilitas tersebut bersifat searah, semakin tinggi tingkat efikasi diri pada siswa maka kemampuan orientasi mobilitas siswa juga akan meningkat serta nilai sig.(2-tailed) sebesar 0,021 lebih kecil dari 0,05 maka dapat diartikan bahwa ada hubungan yang signifikan antara variabel efikasi diri dan kemampuan orientasi mobilitas siswa tunanetra SLB A YKAB Surakarta. Sehingga hipotesis yang diajukan oleh peneliti dinyatakan diterima, yakni terdapat 
hubungan yang positif dan signifikan antara variabel efikasi diri dan kemampuan orientasi mobilitas siswa tunanetra SLB A YKAB Surakarta.

Berdasarkan nilai hasil pengujian korelasi $r_{\text {hitung }}$ sebesar 0,654 maka diperoleh nilai koefisien determinasi $\left(r^{2}\right)$ sebesar 0,427. Nilai koefisien determinasi menunjukkan nilai sumbangan efektif variabel efikasi diri siswa tunanetra terhadap variabel kemampuan orientasi mobilitas siswa tunanetra. Berdasarkan nilai koefisien determinasi maka dapat diketahui nilai sumbangan efektif variabel efikasi diri siswa tunanetra terhadap variabel kemampuan orientasi mobilitas siswa tunanetra sebesar $42,7 \%$.

\section{Pembahasan}

Berdasarkan hasil penelitian, pada variabel efikasi diri dapat diketahui dari 12 subjek penelitian terdapat 1 siswa $(8,33 \%)$ dengan kategori efikasi diri sangat tinggi. Pada kategori efikasi diri tinggi hanya ada 1 siswa (8,33\%). Sedangkan, pada kategori efikasi diri sedang terdapat 8 siswa $(66,67 \%)$ dan pada kategori efikasi diri rendah terdapat 2 siswa (16,67\%). Dari data tersebut diketahui bahwa data yang paling banyak berada pada kategori sedang. Sementara itu, pada variabel kemampuan orientasi mobilitas terdapat 7 siswa $(58,33 \%)$ dengan kategori sangat baik, kategori baik sebanyak 3 siswa (25\%), dan kategori cukup sebanyak 2 siswa $(16,67 \%)$.

Ditinjau dari jenis kelamin, persentase masing-masing jenis kelamin pada subjek penelitian adalah 50\% atau subjek laki-laki sebanyak 6 siswa dan subjek perempuan sebanyak 6 siswa. Pada variabel efikasi diri ditinjau dari jenis kelamin. Subjek yang memiliki efikasi diri pada kategori sangat tinggi meliputi 1 siswa laki-laki (8,33\%), kategori efikasi diri tinggi meliputi 1 siswa laki-laki (8,33\%), kategori efikasi diri sedang meliputi 3 siswa laki-laki (25\%) dan 4 siswa perempuan (33,33\%), kategori rendah meliputi 1 siswa laki-laki $(8,33 \%)$ dan 1 siswa perempuan $(8,33 \%)$. Sedangkan pada variabel kemampuan orientasi mobilitas terdapat 4 siswa laki-laki (33,33\%) dan 3 siswa perempuan (25\%) pada kategori sangat baik, kategori kemampuan orientasi mobilitas baik sebanyak 2 siswa lakilaki $(16,67 \%)$ dan 1 siswa perempuan $(8,33 \%)$, dan pada kategori kemampuan orientasi mobilitas cukup sebanyak 2 siswa perempuan (16,67\%).

Sedangkan dilihat dari tingkat usianya jumlah subjek dengan usia 8 tahun dan 9 tahun masingmasing sebanyak 2 siswa dengan persentase masing-masing sebesar 16,67\%. Subjek dengan usia 10 tahun, 12 tahun, 13 tahun 19 tahun dan 17 tahun memiliki persentase masing-masing 8,33\% atau masing-masing berjumlah 1 siswa. Sedangkan, subjek pada usia 14 tahun memiliki persentase sebesar 25\% atau berjumlah 3 siswa. Ditinjau dari jenjang pendidikan, subjek SDLB memiliki persentase lebih besar dari pada jenjang pendidikan SMPLB yaitu sebesar 58,33\% atau sebanyak 7 siswa. Pada variabel efikasi diri ditinjau dari jenjang pendidikan, subjek dengan kategori efikasi diri sangat tinggi berada pada jenjang SMPLB terdapat 1 siswa (8,33\%), kategori efikasi diri tinggi terdapat 1 siswa $(8,33 \%)$ pada jenjang SDLB, kategori efikasi diri sedang terdapat 4 siswa $(33,33 \%)$ pada masing-masing jenjang SDLB dan SMPLB, dan pada kategori rendah terdapat 2 siswa (16,67\%) pada jenjang SDLB. Sedangkan pada variabel kemampuan orientasi mobilitas, subjek dengan kategori sangat baik pada jenjang SDLB terdapat 2 siswa $(16,67 \%)$ dan 5 siswa $(41,67 \%)$ pada jenjang SMPLB, kategori kemampuan orientasi mobilitas baik sebanyak 3 siswa (25\%) pada jenjang SDLB, dan pada kategori kemampuan orientasi mobilitas cukup terdapat 2 siswa $(16,67 \%)$ jenjang SDLB. 
Berdasarkan hasil analisis yang telah dilakukan menunjukkan bahwa terdapat hubungan yang positif dan signifikan antara variabel efikasi diri dan variabel kemampuan orientasi mobilitas pada siswa tunanetra SLB A YKAB Surakarta. Hal tersebut didukung dengan hasil uji hipotesis yang menggunakan analisis korelasi sederhana dengan spearman rank yang menunjukkan $r_{\text {hitung }}$ sebesar 0,654 dengan nilai $\mathrm{rt}_{\text {abel }}$ 0,591. Sehingga $\mathrm{r}_{\text {hitung }}>\mathrm{r}_{\text {tabel }}$ dengan signifikansi 5\% telah terpenuhi. Sesuai dengan pernyataan Sugiyono (2010), nilai 0,654 dikategorikan memiliki tingkat hubungan yang kuat. Dengan demikian, semakin tinggi efikasi diri maka kemampuan orientasi mobilitas siswa semakin tinggi.

Berdasarkan hasil penelitian yang menyatakan semakin tinggi efikasi diri maka kemampuan orientasi mobilitas siswa di SLB A YKAB Surakarta semakin tinggi. Hal ini sesuai dengan penelitian sebelumnya yang serupa yaitu penelitian yang dilakukan oleh Ema Uzlifatul Jannah tahun 2013 mengenai hubungan efikasi diri dan kemandirian dengan judul Hubungan Antara Self Efficacy dan Kecerdasan Emosional dengan Kemandirian Pada Remaja menunjukkan adanya hubungan antara self efficacy dan kemandirian dimana semakin tinggi self efficacy yang dilakukan remaja akan semakin mandiri remaja tersebut. Efikasi diri adalah keyakinan individu terhadap kemampuan yang dimilikinya dan mampu melakukan hal yang diinginkannya. Menurut Kreitner \& Kinichi (2003) mengemukakan bahwa Self-Efficacy merupakan kepercayaan individu terkait peluang untuk suatu keberhasilan dalam mencapai suatu tugas tertentu. Ketika individu memiliki kemampuan yang sama, individu yang yakin dapat melakukan suatu tugas lebih mungkin mencapai keberhasilan dibandingkan dengan individu yang tidak yakin akan sukses dalam tugas tersebut (ormrod, 2008).

Hasil penelitian menunjukkan bahwa efikasi diri memberikan sumbangan efektif terhadap kemampuan orientasi mobilitas siswa tunanetra SLB A YKAB Surakarta sebesar 42,7\%. Dengan kata lain, kemampuan orientasi mobilitas siswa tunanetra sebesar $42,7 \%$ dipengaruhi oleh efikasi diri, dan sebesar 57,3\% lainnya dipengaruhi oleh faktor-faktor lainnya. Hal ini sesuai dengan pernyataan Hallahan dan Kauffman (dalam Sunanto, 2005) mengemukakan bahwa tunanetra bervariasi dalam keterampilan orientasi mobilitasnya, tidak mudah untuk menentukan apa yang membuat tunanetra memiliki kemampuan lebih baik dalam keterampilan orientasi mobilitas, faktor terpenting yang menentukan kemampuan orientasi mobilitas tunanetra yaitu motivasi untuk mau bergerak. Selain itu, Hidayat dan Suwandi (2013) menjelaskan bahwa orientasi dan mobilitas adalah perhimpunan dan penggunaan indra-indra yang masih berfungsi dengan aman, tepat, efektif, dan efisien tanpa menggantungkan diri pada orang lain. Menurut Sunanto (2005:114-115) orientasi merupakan keterampilan individu dalam memahami lingkungan dan apa hubungannya dengan dirinya, baik secara ruang ataupun waktu. Hosni (1996:44) mengatakan untuk memperlancar proses tercapainya tujuan pendidikan maka keterampilan orientasi mobilitas memiliki peranan yang penting dalam pendidikan. Kedua hasil pendidikan dapat diimplementasikan dalam kegiatan sehari-hari, sehingga membentuk dan membuat fisik yang baik, membentuk rasa percaya diri menjadi lebih baik, membuat komunikasi dan interaksi diri dengan lingkungan. Ketiga dapat mengubah opini masyarakat mengenai siswa tunanetra, dimana pada awalnya tidak memandang keberadaan siswa tunanetra berubah menjadi menghargai dan memperhitungkan keberadaannya dalam lingkungan.

Dengan demikian, efikasi diri memiliki pengaruh terhadap kemampuan orientasi mobilitas 
siswa. Kondisi lingkungan dapat menentukan tinggi rendahnya efikasi diri seseorang. Lingkungan yang mendukung dan mempunyai efikasi diri tinggi dapat memperkirakan adanya kesuksesan bagi seseorang. Lingkungan mendukung namun memiliki efikasi diri rendah, membuat seseorang merasa depresi ketika mengamati oreng lain mampu menyelesaikan tugas yang menurut mereka sukar untuk diselesaikan. Lingkungan yang tidak mendukung bertemu dengan efikasi diri yang tinggi, biasanya lingkungan tersebut akan berusaha diubah agar menjadi lingkungan yang mendukung. Lingkungan yang tidak mendukung serta efikasi diri rendah akan membuat seseorang merasa mudah menyerah, apatis dan merasa tidak berdaya (Fiest \& Gregory, 2008). Bandura (1997) menyatakan individu yang mempunyai perilaku optimis, perasaan hati positif mampu memperbaiki kemampuan untuk memproses informasi secara lebih efisien, mempunyai pandangan bahwa kegagalan bukanlah sesuatu yang merugikan namun justru memotivasi diri untuk melaksanakan yang lebih baik merupakan bentuk dari efikasi diri tinggi sedangkan individu yang memiliki sifat pesimis, perasaan hati yang negatif meningkatkan kemungkinan seseorang untuk marah, merasa bersalah, dan memperbesar kesalahan mereka merupakan bentuk dari efikasi diri rendah. Efikasi diri yang tinggi akan mendorong individu memiliki rasa percaya diri dan keyakinan tentang kemampuan atau kompetensinya untuk mengarahkan motivasi, kemampuan kognisi, dan mengambil tindakan yang diperlukan untuk berpindah tempat, selain itu ketika siswa memiliki orientasi mobilitas yang baik secara langsung maupun tidak langsung memberikan beberapa manfaat yaitu secara psikologis akan meningkatkan rasa percaya diri, manifestasi bentuk tubuh dan cara berjalannya secara fisik akan lebih baik, tunanetra akan lebih bisa bersosialisasi dengan tempat sekitarnya secara sosial, tunanetra meminimalisir meminta bantuan dari orang disekitarnya secara ekonomi, dan kepribadian serta rasa sosial tunanetra lebih dipandang positif dan wajar di lingkungan sekitar ( Munawar \& Suwandi, 2013). Berdasarkan hasil penelitian dan pembahasan yang telah dipaparkan, dapat disimpulkan bahwa terdapat hubungan positif dan signifikan antara efikasi diri dan kemampuan orientasi mobilitas siswa tunanetra SLB A YKAB Surakarta.

\section{Kesimpulan}

Berdasarkan hasil penelitian dan pembahasan yang telah diuraikan pada hasil penelitian dan pembahasan, dapat disimpulkan bahwa terdapat hubungan positif dan signifikan antara efikasi diri dengan kemampuan orientasi mobilitas siswa tunanetra SLB A YKAB Surakarta. Hubungan yang positif memiliki arti bahwa semakin tinggi efikasi diri siswa tunanetra SLB A YKAB Surakarta, maka kemampuan orientasi mobilitas siswa tunanetra SLB A YKAB Surakarta juga akan semakin tinggi. Hasil penelitian ini dapat dijadikan masukan kepada lingkungan sekitar siswa tunanetra, terutama pada lingkungan sekolah dan keluarga siswa tunanetra agar dapat mendorong efikasi diri siswa sehingga siswa memiliki keyakinan dalam dirinya untuk mampu melakukan orientasi mobilitas secara mandiri.

\section{Daftar Rujukan}

Alwisol. (2008). Psikologi Kepribadian. Malang: UPT Penerbitan Universitas Muhammadiyah Malang.

Bandura. (1997). Self Efficay The Exercise of Control. New York: W.H Freeman and Company.

Feist, Jess, \& Gregory, J. Feist. (2008). Theories of Personality Edisi Keenam. Yogyakarta: Pustaka 
Pelajar.

Feist, Jess, \& Gregory, J. Feist. (2010). Teori Kepribadian. Buku 2. Jakarta: Salemba Humanika.

Hidayat, A.AS. \& Suwandi, A. (2013). Pendidikan Anak Berkebutuhan Khusus Tunanetra. Bandung: Luxima.

Hosni, Irham. (1996). Buku Ajar Orientasi dan Mobilitas. Jakarta: Depdikbud Dirjen Dikti.

King, L.A. (2012). Psikologi Umum: The Scince of Psychology: An Appreciative View (Edisi Terjemahan Brian Marwensdy). Jakarta: Salemba Humanika.

Kreintner, R. \& Kinichi, A. (2003). Perilaku Organisasi. Jakarta: Salmeba Empat.

Kustawan, D., \& Meimulyani. (2013). Mengenal Pendidikan Khusus Dan Pendidikan Layanan Khusus Serta Implementasinya. Jakarta: Pt. Luxima Metro Media.

Munawar, Muhdah dan Suwandi, Ate. (2013). Mengenal dan Memahami Orientasi dan Mobilitas. Jakarta: PT.LUXIMA METRO MEDIA.

Ormrod, Jeanne Ellis. (2008). Psikologi Pendidikan Membantu Siswa Tumbuh dan Berkembang Jilid 2. Alih Bahasa: Prof. Dr. Amitya Kumara. Jakarta: Penerbit Erlangga.

Pandji, D. dan Wardhani, W. (2013). Sudahkah Kita Ramah Anak Special Needs. Jakarta: PT Elex Media Komputido.

Pratama, dkk. 2019. “Blind Maps Sebagai Alat Untuk Memudahkan Anak Tunanetra Berorientasi dan Mobilitas di Kampus FKIP UNTIRTA Kota Serang”. Jurnal Unik Pendidikan Luar Biasa. ISSN: 2443-1389.

Sugiyono. (2010). Metode Penelitian: Kuantitatif, Kualitatif dan R\&D. Bandung: Alfabeta.

Sunanto, J. (2005). Potensi Anak Berkelainan Penglihatan. Jakarta: Depdiknas.

Turnbull, A., Turnbull, R., Wehmeyer, M. L., \& Shogren, K. A. (2013). Exceptional Lives: Special Education In Today's Schools.Seventh Edition. USA: Pearson.

Widaningrum, L. (2013). Pendidikan Anak Berkebutuhan Khusus Tunanetra. Jakarta Timur: PT. Luxima Metro Media.

Wahyuno, E. (2013). Orientasi dan Mobilitas. Malang: Universitas Negeri Malang.

Widjaya, A. (2012). Seluk Beluk Tunanetra dan Strategi Pembelajaran. Seleman: Javalitera.

Widjaya, A. (2013). Seluk-beluk Tunanetra \& Strategi Pembelajarannya. Yogyakarta: JAVALITERA. 